\title{
Implementation of Molecular Visualization Program for Chemistry Learning
}

\author{
Risnita Vicky Listyarini \\ Chemistry Education Department, Faculty of Teacher Training and Education, Universitas \\ Sanata Dharma, Jl. Paingan, Krodan, Maguwoharjo, Sleman, Yogyakarta, Indonesia, 55281
}

Corresponding Author e-mail: risnita.vicky@usd.ac.id

Received: June 2021; Revised: June 2021; Published: June 2021

\begin{abstract}
This study aimed to investigate the implementation of molecular visualization programs for improving students' understanding of concepts in chemical bonding. Chemistry learning in chemical bonding was conducted using molecular visualization program ACD/ChemSketch and Avogadro program. Several topics in chemical bonding include molecular geometry, polarity, bond angle, bond length, intermolecular forces and predicting boiling points. This study employs quasi-experimental research One Group Pretest - Posttest design. The subjects of this study were 46 students of undergraduate program in chemistry education department at Universitas Sanata Dharma. This study use test (pretest and pretest) and questionnaire to assess students' perception of implementation of $\mathrm{ACD} / \mathrm{ChemSketch}$ and Avogadro in chemistry learning. Implementation of $\mathrm{ACD} /$ ChemSketch and Avogadro in chemistry learning of chemical bonding gave an effect on students' understanding based on paired t-test $(\mathrm{sig}<0.05)$ and Kruskal-Wallis $(\mathrm{sig}<0.05)$ test. The percentage of students is $45 \%$ with the medium $\mathrm{N}$-gain category and $65 \%$ with the high $\mathrm{N}$-gain category for $\mathrm{ACD} / \mathrm{ChemSketch}$ program. It is $38.46 \%$ with the medium $\mathrm{N}$-gain category and $61.54 \%$ with the high $\mathrm{N}$-gain category for Avogadro program. Students show positive response to the implementation of ACD/ChemSketch and Avogadro program regarding their understanding, motivation and prospective skill for becoming teachers. Molecular visualization program helps the students to understand the chemical bonding topic.
\end{abstract}

Keywords: molecular visualization program; chemistry learning; chemical bonding

How to Cite: Listyarini, R. (2021). Implementation of Molecular Visualization Program for Chemistry Learning. Prisma Sains : Jurnal Pengkajian Ilmu dan Pembelajaran Matematika dan IPA IKIP Mataram, 9(1), 64-75. doi:https://doi.org/10.33394/j-ps.v9i1.3941

https://doi.org/10.33394/j-ps.v9i1.3941

Copyright $@$ 2021, Listyarini This is an open-access article under the CC-BY License. (c) (i)

\section{INTRODUCTION}

Chemistry is a complex science, because a lot of knowledge in this field is related to the molecular level, and students are expected to think on a molecular scale (in terms of interactions between atoms and individual molecules) to explain phenomena at the macroscopic scale (Chandrasegaran et al., 2008; Dori \& Kaberman, 2012; Rayan \& Rayan, 2017). The basic and key topics studied in chemistry include chemical bonding. Concepts related to chemical bonding include covalent bonds, molecules, ions, lattices, and intermolecular force interaction. These concepts are abstract and to understand these concepts. Students must be familiar with mathematical and physical concepts and laws related to the concept of bonds, such as orbitals, electronegativity, electron repulsion, and polarity (Levy Nahum et al., 2010). However, learning about chemical bonding and interaction allows students to think critically to make predictions, and provide explanations, about the physical and chemical properties of a substance.

Students understanding regarding chemical bonding is found to high with $50 \%$ of high school students shows a misconception (Fadillah \& Salirawati, 2018). In particular, misconception is found in the topic of boiling point, hydrogen bonding, geometry of 
molecule, and polarity of molecules for first year undergraduate students (Pérez et al., 2017). These findings suggest there is common failure in chemistry teaching.

It is important to change the methods in chemistry teaching which can improve students' conceptual understanding of chemical bonding. One of the solution to help students' understanding is the use of a three-dimensional (3D) molecular model visualization program. (Rayan et al., 2017). In line with technology-based chemistry learning, the use of 3D molecular visualization programs has the potential to be more effective than traditional approaches. Until now, there are still many chemistry courses at the college level that only use textbooks and two-dimensional pictures to describe molecules. Researchers claim that still images are not sufficient to build understanding of new concepts and phenomena. There needs to be a dynamic image which is very important to promote conceptual understanding (Barak M. \& Hussein-Farraj, 2012). The integration of visual representations such as computerized molecular models, simulations and animations in science learning can help students understand unobservable phenomena (Gilbert, 2005).

Chemistry learning in universities or school should implement technology in courses (Febliza \& Okatariani, 2020). In particular, utilization of computational chemistry programs in chemistry learning still needs to be explored. Computational chemistry programs include molecular editors and molecular visualization programs, among others (Ertl, 2010). Molecular editors are computer programs for creating and modifying representations of chemical structures. Molecular editors can manipulate representations of chemical structures in either simulated two-dimensional (2D) space or three-dimensional (3D) space, each through 2D computer graphics or 3D computer graphics. Molecular editor and visualization programs that operate on windows systems include ChemSketch (ACD/ChemSketch), Chemdraw, Marvinsketch and Avogadro (Avogadro, 2016). The molecule editor and molecular visualization programs either open source or have licenses for academic and teaching purposes.

This study used two programs which are ACD/ChemSketch Freeware and Avogadro Freeware. ACD/ChemSketch is a molecular modeling program used to create and modify images of chemical structures. This program allows molecules and molecular models to be displayed in two and three dimensions, to understand the chemical bond structure and the nature of functional groups. Avogadro is molecular editor and 3D visualisator. Rayan et al. (2017) used Avogadro for chemistry learning in intermolecular force topics. The results show that learning with the molecular model visualization program helps students to have a deeper understanding of the topic of inter-molecular style.

The utilization of a molecular editor and visualization in chemistry learning can help students have a better understanding of chemical bonding. This study aimed to evaluate the implementation of molecular visualization program for chemistry learning in the topic of chemical bonding.

\section{METHOD}

\section{Research participant}

The subjects of this study were 46 students of undergraduate program in chemistry education department at Universitas Sanata Dharma.

\section{Research design}

This study employed Quasi Experiment with One Group Pretest Posttest design. The programs used in this study were ACD/ChemSketch Freeware (can be downloaded from (https://www.acdlabs.com/resources/freeware/chemsketch/) and Avogadro Freeware (can be downloaded from (https://avogadro.cc/). Implementation of molecular visualization programs is applied in the topic as presented in Table 1.

Table 1. Topic and subjects of study

\begin{tabular}{llll}
\hline No & Topic & Program & Subject \\
\hline 1 & Molecular geometry and polarity & ACD/ChemSketch & $1^{\text {st }}$ year (26 students) \\
\multicolumn{2}{l}{ Prisma Sains: Jurnal Pengkajian Ilmu dan Pembelajaran } & Matematika dan IPA IKIP Mataram, Jun. 2021. Vol. 9, No.1
\end{tabular}




\begin{tabular}{llll}
\hline No & Topic & Program & Subject \\
\hline 2 & Bond angle and bond length & ACD/ChemSketch & $1^{\text {st }}$ year $(26$ students $)$ \\
3 & Intermolecular forces & Avogadro & $3^{\text {rd }}$ year $(20$ students $)$ \\
4 & Predicting Boiling points & Avogadro & $3^{\text {rd }}$ year $(20$ students $)$ \\
\hline
\end{tabular}

The data collection stage adapting and modifying based on Sugiyono (2012).

\begin{tabular}{|lll|}
\hline$P_{1}$ & $X$ & $P_{2}$ \\
\hline
\end{tabular}

X: Chemistry Learning of chemical bonding using ChemSketch and Avogadro.

P1: Pretest score

P2: Posttest score

The learning design consists of three stages as presented in Figure 1.
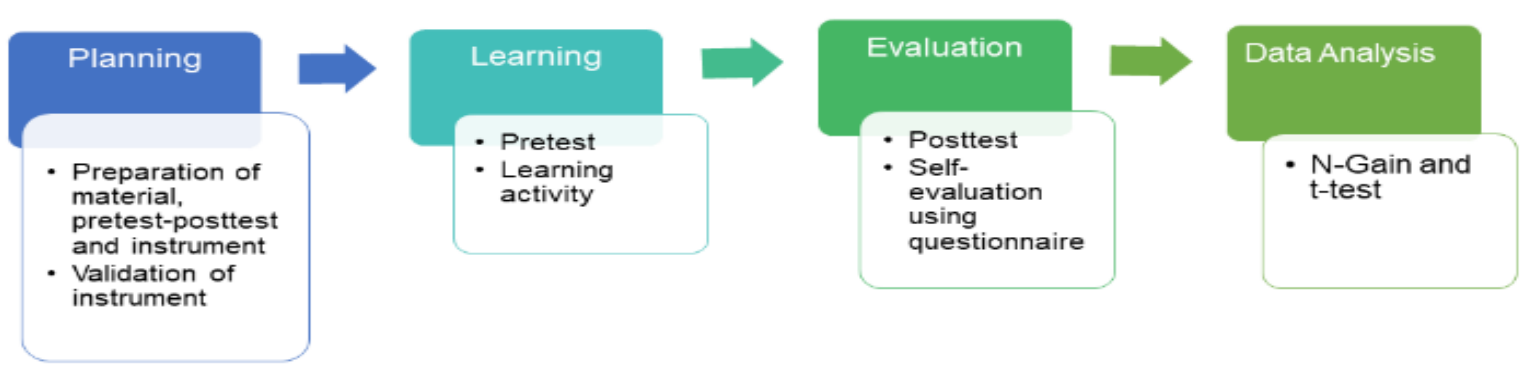

Figure 1. Learning design

At the planning step, the preparation of material is made including video tutorial, pretest, posttest and instrument of questionnaire. The validation of the instrument is performed in this step through expert judgement from the aspect of substantion, construction and language (Laksono et al., 2017). In the learning step, students are given an individual test pretest on related topics using Learning Management System (LMS) of Universitas Sanata Dharma. Learning activities are performed in this step (Hariyono et al., 2020). Students can view video tutorials by lecturers on how to download, install and use the ACD/ChemSketch and Avogadro program. At his step, student perform independent tasks given by the lecturer using ACD/ChemSketch and Avogadro program. Independent task involves in solving on questions using the $\mathrm{ACD} / \mathrm{ChemSketch}$ and Avogadro program. In evaluation step, the posttest on related topics is given for each student using LMS. The selfevaluation is performed using a questionnaire to assess students' perception on implementation of chemistry learning using molecular visualization program.

\section{Data analysis}

Data analysis is performed for finding N-gain. Paired t-test is performed. Pretest and posttest were analyzed using normalize gain (N-gain) (Hake, 1999).

The data were analyzed using criteria in Table 2.

$$
N-\text { Gain }=\frac{\text { Pretest Score }- \text { Posttest Score }}{\text { Maximal Score }- \text { Pretest Score }}
$$

Table 2. N-gain Criteria Interpretation

\begin{tabular}{cc}
\hline Score & Criteria Interpretation \\
\hline $0.70<\mathrm{N}$-gain & High \\
$0.30<\mathrm{N}$-gain $\leq 0.70$ & Medium \\
$\mathrm{N}$-gain $\leq 0.30$ & Low \\
\hline
\end{tabular}


The normality of data and paired t-test is performed using SPSS. The SPSS results is used to analyze the implementation of Chemistry Learning of chemical bonding using $\mathrm{ACD} / \mathrm{ChemSketch}$ and Avogadro program.

\section{RESULTS AND DISCUSSION}

Students performed the learning activities using their personal computer/laptop. Video and document tutorials are prepared by lecturer on how to download, install and use the ACD/Chemsketch and Avogadro program. Documents and video tutorials are uploaded to the LMS and students can download from the LMS. A tutorial document on how to download, install and use the ACD/Chemsketch program is presented in Figure 2. A video tutorial on the use of the ACD/Chemsketch program is made. Some basic features of how to draw twodimensional (2D) molecules are explained in the video tutorial. After drawing the 2D structure, the structure can be transformed into a three-dimensional (3D). The video tutorial has also explained how to change the $3 \mathrm{D}$ representation as shown in Figure 3 . In the $\mathrm{ACD} /$ Chemsketch program, several 3D representations are known, among them are wireframe, sticks, ball and sticks, spacefill, dots only. Students are introduced to some 3D representations of molecules because the forms of 3D representations of these molecules also appear in chemistry books.

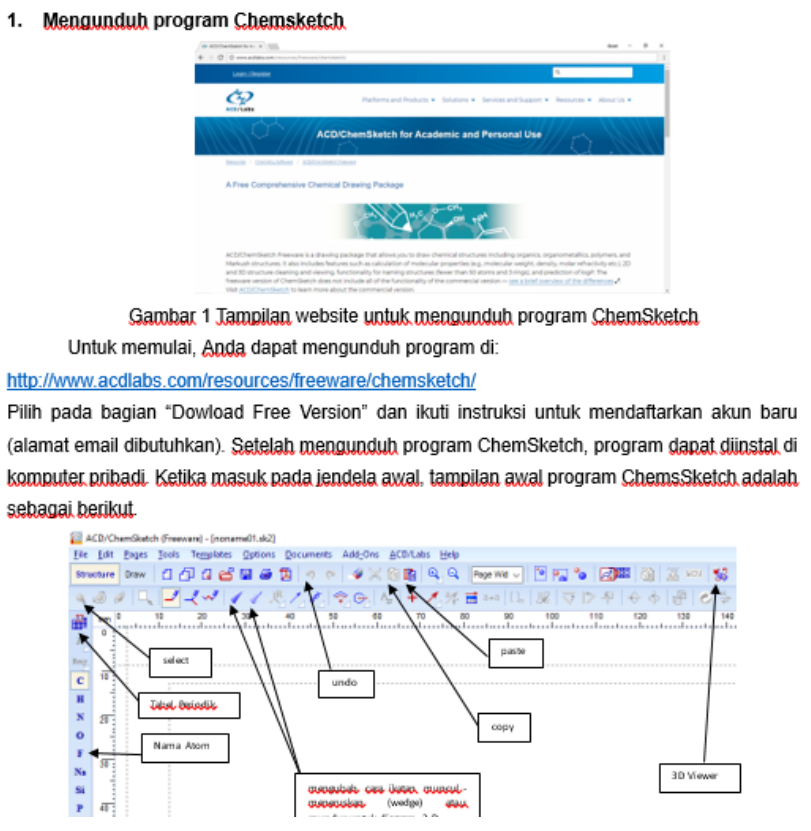

Figure 2. Tutorial of using ACD/Chemsketch program
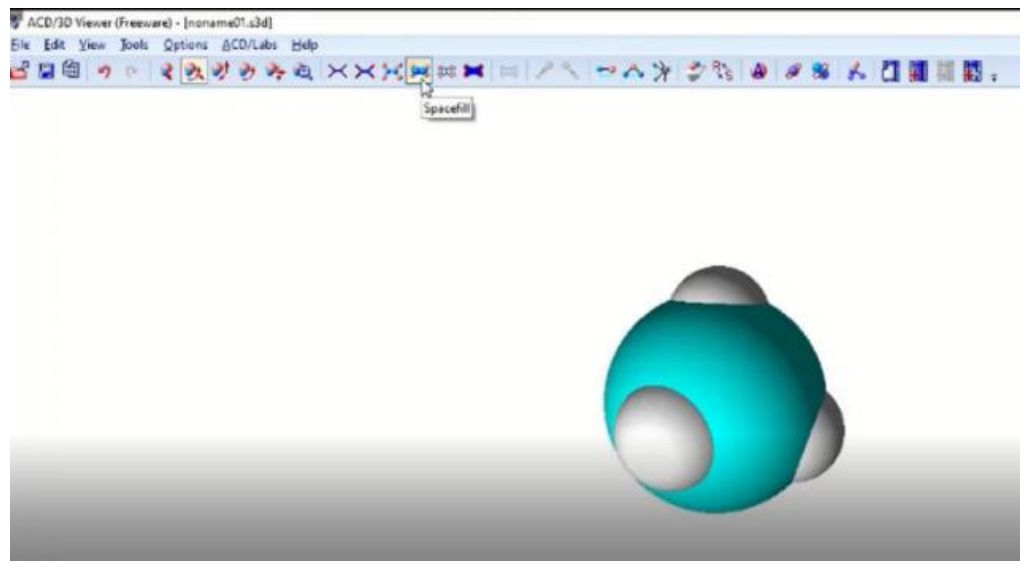

Figure 3. Screenshoot of tutorial video for making three-dimensional (3D) structure 
After watching the documents and video tutorials, students perform tasks independently. Students answer the question using ACD/Chemsketch and explain their answer by connecting the theories based on chemistry literature. The example of individual task performed by students is shown in Figure 4.

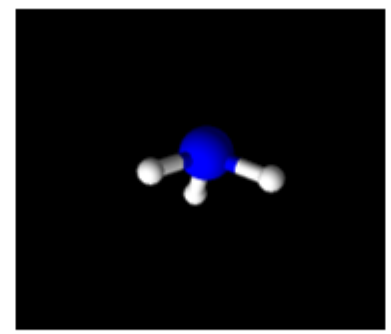

b. Bentuk geometri molekul berdasarkan VSEPR dan teori domain molekul berdasarkan hasil dari program chemsketch yaitu segitiga piramida atau trigonal piramida. Berdasarkan teori molekul $\mathrm{NH}_{3}$ memiliki bentuk molekul atau geometri yaitu segitiga piramida. Dalam molekul $\mathrm{NH}_{3}$ terdapat 1 pasang pasangan elektron bebas (PEB) dan 3 pasang pasangan elektron ikatan (PEI). Dalam molekul $\mathrm{NH}_{3}$ susunan keseluruh keempat pasangan elektron adalah tetrahedral, namun dalam $\mathrm{NH}_{3}$ terdapat satu pasangan elektron bebas (PEB), sehingga geometri molekul $\mathrm{NH}_{3}$ merupakan segitiga piramida. Pasangan elektron bebas menolak pasangan elektron ikatan lebih kuat, sehingga ikatan $\mathrm{NH}$ terdorong untuk lebih dekat satu dengan lainnya (Chang, 2005).

Figure 4. Example of individual task performed by student in topic of molecule geometry

The video and document tutorial are also prepared for Avogadro program. Documents and video tutorials are uploaded to the Learning Management System (LMS) and students can download from the LMS. Students perform and answer individual tasks given by the lecturer using Avogadro program. The example of students' individual tasks performed using Avogadro program is shown in Figure 5.

e. Gaya intermolekular pada ketiga molekul mempengaruhi titik didih yang dimilikinya. Ketiga molekul sama-sama memiliki gaya intermolekular london karena ikatannya terjadi pada molekul non-polar dan non-polar. Perbedaannya terletak pada titik didih yang dimilikinya. Gaya intermolekular london dipengaruhi oleh bentuk molekulnya. Semakin besar area permukaannya, maka gaya london semakin kuat. Gaya london semakin kuat, maka titik didihnya semakin tinggi. Hal inilah yang menyebabkan pentana memiliki titik didih paling tinggi dibandingkan dua molekul lain. Molekul 2,2-dimetil propana memiliki titik didih paling rendah karena memiliki bentuk molekul yang menyerupai bola, sehingga gaya londonnya berkurang. Oleh karena itu, titik didihnya yang paling rendah.
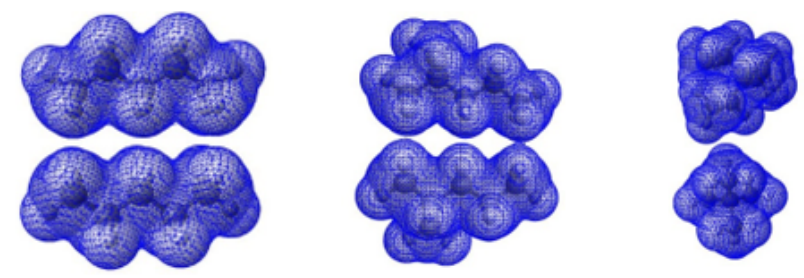

n-pentana $>2$-metil butana $>2,2$-dimetil butana (TD)

Figure 5. Example of individual task performed by student in topic intermolecular force. 
Pretest and posttest scores are presented in Table 2. The average score of posttest (84.62 and 90) after using ACD/ChemSketch and Avogadro program for learning activities. Based on the increasing number in posttest average, it can be concluded that learning activities using $\mathrm{ACD} / \mathrm{ChemSketch}$ and Avogadro program increase the students' understanding of chemical bonding.

Tabel 2. Pretest and Posttest Score

\begin{tabular}{lllll}
\hline Program & ACD/Chemsketch & Avogadro & \\
\hline Component & Pretest & Posttest & Pretest & Posttest \\
Number of students & 26 & 26 & 20 & 20 \\
Lowest score & 10 & 60 & 20 & 60 \\
Highest score & 80 & 100 & 80 & 100 \\
Average score & 32.50 & 84.62 & 54.5 & 90 \\
Standard Deviation & 17.16 & 11.57 & 18.49 & 6.49 \\
\hline
\end{tabular}

$\mathrm{N}$-gain category percentage is shown in Table 3. It can be seen $\mathrm{N}$-gain category of using ACD/ChemSketch and Avogadro program for chemistry learning both are classified in medium and high categories. The percentage of students is $45 \%$ with the medium $\mathrm{N}$-gain category and $65 \%$ with the high $\mathrm{N}$-gain category for ACD/ChemSketch program. Besides, it is $38.46 \%$ with the medium $\mathrm{N}$-gain category and $61.54 \%$ with the high $\mathrm{N}$-gain category for Avogadro program.

Tabel 3. N-gain category percentage

\begin{tabular}{lll}
\hline Program & Category & Percentage \\
\hline ACD/Chemsketch & High & $65 \%$ \\
& Medium & $45 \%$ \\
& Low & 0 \\
\hline Avogadro & High & $61.54 \%$ \\
& Medium & $38.46 \%$ \\
& Low & 0 \\
\hline
\end{tabular}

The tests of normality Shapiro-Wilk are performed. For ACD/ChemSketch program, pretest and posttest score follow a normally distributed with sig. $>0.05$ (Table 4.). For investigating the difference in pretest and posttest, it is performed paired t-test. For Avogadro program, pretest score follows a normal distribution with sig $>0.05$ however posttest score does not follow normal distribution with sig $<0.05$ (Table 4.). Because posttest score does not normally distributed, it uses the Kruskal-Wallis test to compare pretest and posttest.

Tabel 4. Normality of data, paired t-test and Kruskal-Wallis test

\begin{tabular}{llllll}
\hline Program & & \multicolumn{2}{l}{ Shapiro-Wilk } & \multicolumn{2}{l}{ Paired t-test } \\
\cline { 2 - 5 } & & Statistic & df & Sig. & Sig. \\
\hline \multirow{2}{*}{ ACD/Chemsketch } & pretest & 0.927 & 26 & 0.067 & 0.000 \\
\cline { 2 - 5 } & posttest & 0.900 & 26 & 0.139 & \\
\hline Program & & Shapiro-Wilk & & Kruskal-Wallis test \\
\cline { 2 - 5 } & & Statistic & df & Sig. & Sig \\
\hline Avogadro & pretest & 0.936 & 20 & 0.203 & 0.000 \\
\cline { 2 - 5 } & posttest & 0.793 & 20 & 0.001 & \\
\hline
\end{tabular}

Table 4 show the paired t-test pretest and posttest score for implementation of $\mathrm{ACD} /$ Chemsketch. The sig $<0.05$ shows that there is a difference between pretest and posttest score. It can be inferred that learning activities using ACD/ChemSketch program in chemical bonding affect in students' understanding. The Kruskal-Wallis test pretest and posttest score for implementation Avogadro program is also showed in Table 4. The value $(\operatorname{sig}<0.05)$ shows the difference between pretest and posttest scores. It can be concluded that 
learning activities using Avogadro program in chemical bonding affect in students' understanding.

Students' perception of the implementation of chemistry learning using molecular visualization program is assessed using questionnaire. The questionnaire consists of closedended and open-ended questions. The closed-ended question is assessed using 5-point Likert Scale: (1) Strongly disagree; (2) Disagree; (3) Neither agree nor disagree; (4) Agree; (5) Strongly agree. The open-ended question is analyzed by descriptive analysis. The results are shown in Table 5.

Tabel 5. The results of questionnaire

\begin{tabular}{|c|c|c|c|}
\hline $\mathrm{No}$ & Statement & Percentage $(\%)$ & Response \\
\hline 1 & $\begin{array}{l}\text { I have a better understanding regarding the bond } \\
\text { length with the help of the ACD/ChemSketch } \\
\text { program }\end{array}$ & 70.76 & Agree \\
\hline 2 & $\begin{array}{l}\text { I have a better understanding regarding the bond } \\
\text { angle material with the help of the ACD/ChemSketch } \\
\text { program }\end{array}$ & 74.61 & Agree \\
\hline 3 & $\begin{array}{l}\text { I have a better understanding regarding the dipole } \\
\text { moment material with the help of the } \\
\text { ACD/ChemSketch }\end{array}$ & 61.53 & Agree \\
\hline 4 & $\begin{array}{l}\text { I have a better understanding regarding the molecular } \\
\text { polarity material with the help of the } \\
\text { ACD/ChemSketch program }\end{array}$ & 65.38 & Agree \\
\hline 5 & $\begin{array}{l}\text { I have a better understanding regarding the dipole } \\
\text { moment with the help of the Avogadro program }\end{array}$ & 64.61 & Agree \\
\hline 6 & $\begin{array}{l}\text { I have a better understanding regarding the } \\
\text { intermolecular force with the help of the Avogadro }\end{array}$ & 63.84 & Agree \\
\hline 7 & $\begin{array}{l}\text { I have a better understanding of the relationship } \\
\text { between the intermolecular force and the physical } \\
\text { properties of molecules (eg boiling point) with the } \\
\text { help of the Avogadro program }\end{array}$ & 61.53 & Agree \\
\hline 8 & $\begin{array}{l}\text { I am interested in learning about 3D shapes of } \\
\text { molecular geometry using the ACD/ChemSketch } \\
\text { program. }\end{array}$ & 80.76 & $\begin{array}{l}\text { Strongly } \\
\text { Agree }\end{array}$ \\
\hline 9 & $\begin{array}{l}\text { I am interested in learning about bond length using } \\
\text { the ACD/ChemSketch program. }\end{array}$ & 72.30 & Agree \\
\hline 10 & $\begin{array}{l}\text { I feel interested in learning about bonding angles } \\
\text { using the ACD/ChemSketch program. }\end{array}$ & 68.46 & Agree \\
\hline 11 & $\begin{array}{l}\text { I feel interested in learning about dipole moments } \\
\text { using the ACD/ChemSketch program. }\end{array}$ & 64.61 & Agree \\
\hline 12 & $\begin{array}{l}\text { I am interested in learning about molecular polarity } \\
\text { using the ACD/ChemSketch program. }\end{array}$ & 68.46 & Agree \\
\hline 13 & $\begin{array}{l}\text { I am interested in learning about 3D shapes of } \\
\text { molecular geometry using the Avogadro program. }\end{array}$ & 72.30 & Agree \\
\hline 14 & $\begin{array}{l}\text { I feel interested in learning about dipole moments } \\
\text { using the Avogadro program. }\end{array}$ & 69.23 & Agree \\
\hline 15 & $\begin{array}{l}\text { I am interested in learning about intermolecular force } \\
\text { using the Avogadro program. }\end{array}$ & 68.46 & Agree \\
\hline 16 & $\begin{array}{l}\text { Tutorials and explanations are provided to help } \\
\text { complete the task. }\end{array}$ & 72.30 & Agree \\
\hline 17 & $\begin{array}{l}\text { Self-independent tasks with ACD/ChemSketch and } \\
\text { Avogadro programs helped me understand important }\end{array}$ & 71.53 & Agree \\
\hline
\end{tabular}




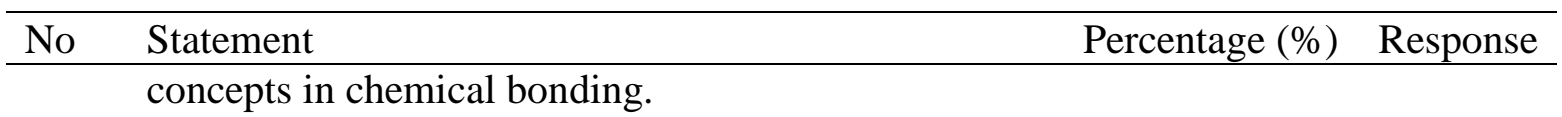

\begin{tabular}{|c|c|c|c|}
\hline 18 & $\begin{array}{l}\text { Self-independent task with the ACD/ChemSketch } \\
\text { and Avogadro program is a learning-centered on me } \\
\text { because I contribute to understanding important } \\
\text { concepts in chemical bonding. }\end{array}$ & 72.30 & Agree \\
\hline
\end{tabular}

Seventeen of eighteen statements are found to be Agree and one statement is Strongly Agree. Students agree for having a better understanding in learning about bond length (70\%); bond angle (74.61\%); dipole moment (61.53\%); molecular polarity $(63.58 \%)$ using the ACD/ChemSketch program. Students agree $(63.84 \%)$ that they have a better understanding regarding the intermolecular force with the help of the Avogadro program. Also, $61.53 \%$ of the students agree that they have a better understanding of the relationship between the intermolecular force and the physical properties of molecules (eg. boiling point) with the help of the Avogadro program.

Eighty percent $(80 \%)$ of the students strongly agree for feeling very interested in learning about 3D shapes of molecular geometry using ACD/ChemSketch program. Students agree for feeling interested in learning about bond length $(72.30 \%)$; bond angle $(68.46 \%)$; dipole moment (64.61\%); molecular polarity (68.46\%) using the ACD/ChemSketch program. Besides, students agree for feeling interested in learning about dipole moments $(69.23 \%)$ and intermolecular force (68.46 using the Avogadro program. $71.53 \%$ of students agree that selfindependent tasks using ACD/ChemSketch and Avogadro programs helped them understand important concepts in chemical bonding.

This study shows the implementation of molecular visualization program ACD/ChemSketch and Avogadro in chemistry learning particularly in chemical bonding. There is an effect in students' understanding by using ACD/ChemSketch and Avogadro. Chemical bonding concepts contain abstract concept which needs student' imagination to understand the concept. There is a need for three-dimensional model which helps students understand the concept and explain the reason behind it. Instead of using conventional 3D molecular model, this study employs technology in teaching by using the 3D visualization program in students' personal computers or laptops. 3D visualization programs provide tools that allow the students to build their concept and reasoning by incorporating guided-inquiry activities (Seery \& McDonnell, 2013).

The inclusion of video and document tutorials is proven to help students in finishing their tasks. As many as $72.30 \%$ (Table 5.) of the students agree that tutorials and explanations are provided to help complete the task. Pre-learning activities in the form of video tutorials or interactive discussions help the students to prepare and understand the topic (Seery, 2013). Learning activities supported by video tutorial make the students perform better in selforganized learning in particular to improve skills in using software (Worlitz et al., 2016). Video tutorial is described as cost-efficient tool to help students solving the problem in chemistry learning (He et al., 2012).

The finding of this study is in line with the finding from (Rayan et al., 2017) in which incorporation of molecular visualization programs in chemistry learning will increase students' understanding of the important concept. The number of experiments or chemistry learning activities which implementing molecular visualization program increase in recent years (Garcia-Ruiz et al., 2014; Morsch \& Lewis, 2015). Introducing the students to several molecular visualization tools can help the students to develop visualization skills. Visual literacy skill including drawing interpretation of 3D representation to explain concept is important (Roche Allred et al., 2017). Visual literacy can be developed by introducing submicro drawing questions to investigate students' conceptual understanding. However, 
teacher's lecture and textbook often represented atom and chemical bonding in 2D thus limit the student to explore the aspect of their drawing (Dicksona et al., 2017).

This study promotes students' centered learning by allowing students to perform selfindependent tasks instead of traditional lectures. Students-centered learning promotes students' engagement in chemistry learning. Student engagement is essential and connected to students' motivation for learning (Bolte et al., 2013; Wood, 2019). Self-independent tasks also allow students to take responsibility for their learning (Mataka \& Kowalske, 2015). $71.53 \%$ of the students agree that self-independent tasks with ACD/ChemSketch and Avogadro programs help them understand important concepts in chemical bonding. This finding is supported by students' responses to open-ended questionnaires.

P.18: "In this ACD/ChemSketch program, I can make molecular structures in $2 D$ and $3 D$. I can find out the molecular geometry, bond length, and the angle of the bond formed. In addition, I can also use this program to make complex structures, Lewis structures, and some chemical apparatus equipment using the template"

P.23: "I can draw molecular shapes and structures by myself rather than make only an imagination. Moreover, the length of the bond and the angle of bonding are better known using this program"

P.5: "Self-assignment task with Avogadro program made me study chemical concepts such as molecular shape, molecular structure, the influence of intermolecular force in the boiling point of compounds"

However, there is a student with some technical problem.

P.21: "Through self-assignment with the ACD/ChemSketch program, I did understand better, but the program is running slow in my laptop when changing molecule from $2 D$ into $3 D$ representation"

Students in the chemistry education department are expected to become chemistry in the future. Skilled and professional prospective teacher includes information and communication technologies (ICT) literacy. ICT literacy consists of using of software in teaching. Enhancing ICT literacy for prospective teachers will affect the active utilization of technology in their teaching methods in the future (Şen \& Temel, 2016). The experience of using ICT in learning activities will promote the possibility of utilization of ICT in terms of software for chemistry learning and teaching in the future (Mahdum et al., 2019).

P.22: "When I became a teacher, this program will help me in making a variety of molecular structures. I hope I can practice directly to students so chemistry learning become various and not too monotonous using books/whiteboards"

P15: "Later when I became a teacher, I will able to visualize the geometry of the molecule so that students understand the geometry of the molecule clearly. I will also encourage students to use this program so that students can explore everything they want to know"

Students show positive responses with the utilization of ACD/ChemSketch and Avogadro program for learning which can be seen from the questionnaire.

P2: "I like to use the Avogadro program. Even though at first I felt difficult but I tried to explore myself so that I could understand better how to run the program" 
P10: "I felt a little confused because this is the first time operating this application. I still need more time to explore and understand the program. However, this learning activity helps us in preparing to become prospective teacher"

Students' response shows positive response towards the implementation of chemistry learning using molecular visualization program. In general, students feel interested and happy to explore new learning activities and skills as they are preparing to become prospective teachers.

\section{CONCLUSION}

This study shows that implementation of molecular visualization program ACD/ChemSketch and Avogadro in chemistry learning of chemical bonding gave an effect on students' understanding based on paired t-test analysis and Kruskal-Wallis test of pretest and posttest score. Molecular visualization program helps the students to visualize concepts in chemical bonding and explain the reason behind important topics such as molecular geometry, polarity, bond angle, bond length, intermolecular forces and predicting boiling points. Students show positive response regarding the implementation of molecular visualization programs in chemistry learning regarding their understanding, motivation and prospective skill for becoming teacher. Chemistry learning using molecular visualization program is interesting yet challenging with a small number of students still find difficulties in operating the molecular visualization program

\section{RECOMMENDATION}

The limitation of this study is the difference of molecular visualization program implemented in different classes. It cannot be compared the difference between two classes. The further studies performed by prospective researcher can implement the same molecular visualization program in different classes and compared the results between two classes.

\section{ACKNOWLEDGMENT}

The author would like to thank the Institute for Research and Community Service (LPPM) Universitas Sanata Dharma for providing the research grant.

\section{REFERENCES}

ACD/ChemSketch.

https://www.acdlabs.com/resources/freeware/chemsketch/

Retrieved

from

Avogadro. (2016). Retrieved from https://avogadro.cc/

Barak M., \& Hussein-Farraj, R. (2012). Integrating model-based learning and animations for enhancing students' understanding of proteins structure and function. Research in Science Education, 43(2), 619-636.

Bolte, C., Streller, S., \& Hofstein, A. (2013). How to Motivate Students and Raise Their Interest in Chemistry Eduaction. In I. E. a. A. Hofstein (Ed.), Teaching Chemistry - A Studybook (pp. 67-95): Sense Publisher.

Chandrasegaran, A. L., Treagust D.F., \& Mocerino, M. (2008). An evaluation of a teacher intervention to promote students' ability to use multiple levels of representation when describing and explaining chemical reactions. Research in Science Education, 38(2), 237-248.

Dicksona, H., Thompsona, C., \& O'Toole, P. (2017). Developing a Common Visual Literacy Amongst First Year Chemistry Students. International Journal of Innovation in Science and Mathematics Education, 25(1), 1-13.

Dori, Y. J., \& Kaberman, Z. (2012). Assessing high school chemistry students' modeling subskills in a computerized molecular modeling learning environment. Instructional Science, 40, 69-91. 
Ertl, P. (2010). Molecular structure input on the web. Journal of Cheminformatics, 2(1).

Fadillah, A., \& Salirawati, D. (2018). Analysis of misconceptions of chemical bonding among tenth grade senior high school students using a two-tier test. 2021, 080002. doi:10.1063/1.5062821

Febliza, A., \& Okatariani, O. (2020). The Development of Online Learning Media by Using Moodle for General Chemistry Subject. Journal of Educational Science and Technology (EST), 6(1), 40. doi:10.26858/est.v6i1.12339

Garcia-Ruiz, M. A., Santana, P. C., \& Molina, M. (2014). Using Effective Stereoscopic Molecular Model Visualizations in Undergraduate Classrooms. International Journal for Cross-Disciplinary Subjects in Education (IJCDSE),, 5(1).

Gilbert, J. K. (2005). Visualization: A metacognitive skill in science and science education. Visualization in Science Education (Vol. 1). Netherlands: Springer

Hake, R. (1999). Analyzing Change/ Gain Score. Indiana: Indiana University.

Hariyono, E., Prahani, B. K., \& Mardiyanti, M. (2020). Volcano Project Design: Innovation In Geoscience Learning. Prisma Sains : Jurnal Pengkajian Ilmu dan Pembelajaran Matematika dan IPA IKIP Mataram, 8(2), 139. doi:10.33394/j-ps.v8i2.3267

He, Y., Swenson, S., \& Lents, N. (2012). Online Video Tutorials Increase Learning of Difficult Concepts in an Undergraduate Analytical Chemistry Course. Journal of Chemical Education, 89(9), 1128-1132. doi:10.1021/ed200685p

Laksono , E. W., Rohaeti, E., Suyanta, \& Irwanto. (2017). INSTRUMEN PENILAIAN KEMAMPUAN BERPIKIR ANALITIS DAN KETERAMPILAN PROSES SAINS KIMIA. Jurnal Kependidikan, 1(1), 100-110.

Levy Nahum, T., Mamlok-Naaman, R., Hofstein, A., \& Taber, K. S. (2010). Teaching and learning the concept of chemical bonding. Studies in Science Education, 46(2), 179207. doi:10.1080/03057267.2010.504548

Mahdum, M., Hadriana, H., \& Safriyanti, M. (2019). Exploring Teacher Perceptions and Motivations to ICT Use in Learning Activities in Indonesia. Journal of Information Technology Education: Research, 18, 293-317. doi:10.28945/4366

Mataka, L. M., \& Kowalske, M. G. (2015). The influence of PBL on students' self-efficacy beliefs in chemistry. Chemistry Education Research and Practice, 16(4), 929-938. doi:10.1039/c5rp00099h

Morsch, L. A., \& Lewis, M. (2015). Engaging Organic Chemistry Students Using ChemDraw for iPad. Journal of Chemical Education, 92(8), 1402-1405. doi:10.1021/acs.jchemed.5b00054

Pérez, J. R. B., Pérez, M. E. B., Calatayud, M. L., García-Lopera, R., Montesinos, J. V. S., \& Gil, E. T. (2017). Student's Misconceptions on Chemical Bonding: A Comparative Study between High School and First Year University Students. Asian Journal of Education and e-Learning, 5(1), 1-16.

Rayan, B., \& Rayan, A. (2017). Avogadro Program for Chemistry Education: To What Extent can Molecular Visualization and Three-dimensional Simulations Enhance Meaningful Chemistry Learning? World Journal of Chemical Education, 5(4), 136141. doi:10.12691/wjce-5-4-4

Roche Allred, Z. D., Tai, H., Bretz, S. L., \& Page, R. C. (2017). Using PyMOL to Explore the Effects of $\mathrm{pH}$ on Noncovalent Interactions between Immunoglobulin $\mathrm{G}$ and Protein A: A Guided-Inquiry Biochemistry Activity. Biochem Mol Biol Educ, 45(6), 528-536. doi:10.1002/bmb.21066

Seery, M. K. (2013). Harnessing Technology in Chemistry Education. New Directions, 9(1), 77-86. doi:10.11120/ndir.2013.00002

Seery, M. K., \& McDonnell, C. (2013). The application of technology to enhance chemistry education. Chem. Educ. Res. Pract., 14(3), 227-228. doi:10.1039/c3rp90006a

Şen, Ş., \& Temel, S. (2016). An Analysis of Prospective Chemistry Teachers' Attitudes towards Information and Communication Technologies, and of Their Confidence in 
Technological and Pedagogical Content Knowledge. Participatory Educational Research, spil6(2), 1-10. doi:10.17275/per.16.spi.2.1

Sugiyono. (2012). Metode Penelitian Kuantitatif Kualitatif dan R\&D. Bandung: Alfabeta.

Wood, R. (2019). Students' Motivation to Engage with Science Learning Activities through the Lens of Self-Determination Theory: Results from a Single-Case School-Based Study. EURASIA Journal of Mathematics, Science and Technology Education, 15(7). doi:10.29333/ejmste/106110

Worlitz, J., Stabler, A., Peplowsky, S., \& Woll, R. (2016). Video Tutorials: An Appropriate Way of Teaching QM Tools Applied with Software. Quality Innovation Prosperity, 20(2), 169. doi:10.12776/qip.v20i2.754 